\title{
THE MODERN AMERICAN UNIVERSITY AND EARLY ENGLISH DEPARTMENTS: GERMAN MODELS AND AMERICAN PRACTICE, 1870-1920 ${ }^{1}$
}

\author{
Yrd. Doç. Dr. Gerard PAULSEN \\ Celal Bayar Üniversitesi, Fen Edebiyat Fakültesi, \\ İngiliz Dili ve Edebiyatı Bölümü
}

\begin{abstract}
The English department first came into existence in the modern American university; its theoretical apparatus, research methodology and pedagogic practices were directly derived from nineteenth-century German philology. Whereas the postCivil War educational reformers who constructed the modern American academic system adapted the German university model to fit it to the social and cultural patterns of America, professors in early English departments simply borrowed German philology and method and, without substantially adding to it or altering it, used it over the next five or six decades as the basis intense research publication. This paper aims to show why American professors of English were so enamored of German philology and, more importantly, what kind of research it enabled them to produce. In addition, it will attempt to examine the consequences of the philological orientation of early English departments and to explain why, when the New Critics finally supplanted philologists and their literary historian descendants, philology almost completely disappeared from English departments.
\end{abstract}

Keywords: American higher education, the modern American university, philology, German philology, American philology, nineteenth-century linguistics, transnationalism, English departments, English literature, English major.

\section{MODERN AMERIKKAN ÜNIVERSITESI VE İLK İNGILIZCE BÖLÜMLERI:: ALMAN MODELLERİ VE AMERİKAN UYGULAMASI, 1870-1920}

\section{ÖZ}

Ingiliz Dili bölümü ilk olarak modern Amerikan üniversitesinde var olmuştur. Teorik aygıtını, araştırma metodolojisini ve pedagojik uygulamalarını ise doğrudan 19. Yüzyll Alman filolojisinden almıştır. Modern Amerikan akademik sistemini kuran $\dot{I}_{c ̧}$

\footnotetext{
${ }^{1}$ Makalenin geliş tarihi: 01.02.2015

Makalenin kabul tarihi: 13.03.2015
} 
Savaş sonrası eğitim reformcular Alman üniversite modelini Amerika'nın sosyal ve kültürel yapısına uydurmaya çalışırken erken İngiliz Dili bölümlerindeki akademisyenler ise ciddi bir ekleme veya değişiklik yapmadan doğrudan Alman filolojisini ve metodunu ödünç almışlar ve takip eden elli veya altmış yıl boyunca araştırma ve yayınlarının temeli olarak kullanmışlardır. Bu çalışma, Amerikalı akademisyenlerin Alman filolojisine hayranlıklarının sebeplerini ve daha da önemlisi bu filolojinin ne tür araştırmalar üretmelerini sağladığını göstermeyi amaçlamaktadır. Ayrıca, ilk İngiliz Dili bölümlerinin filoloji yöneliminin sonuçlarını ve Yeni Eleştiricilerin; filologların ve edebiyat tarihçilerinin yerini aldiğl zaman filolojinin Ingiliz Dili bölümlerinden nerdeyse tamamen kaybolmasının sebeplerini incelemeye çalışacaktır.

Anahtar Kelimeler: Amerikan yükseköğretimi, modern Amerikan üniversitesi, filoloji, Alman filolojisi, Amerikan filolojisi, 19. yüzyll dilbilimi, ulusötesicilik, Ingiliz Dili bölümleri, İngiliz Edebiyatı, Íngiliz Dili anadall.

\section{Introduction}

The history of the English department is intimately connected with the emergence of the modern American university in the post-Civil War period, for it was in the transformed traditional colleges and newly established universities that English departments were first established. Yet, whereas the educational reformers who created the modern American academic system adapted the German university model to fit it to the patterns of American society and governance, professors in early English departments made few changes to the theory and methods they borrowed from German philology. The academic system established by the American educational reformers of the $1860 \mathrm{~s}$ and 1870 s proved capable of evolving in concert with the changing needs of American society, industry and business; this system has remained, in all but a few details, largely intact right up to the present. In contrast, the philological theory and methods that dominated English departments from their inception in the 1870 s through to the 1920s (and, in a less rigorously theoretical form known as literary history, until the late 1940s) subsequently disappeared almost without trace from English departments. New Criticism, which replaced philology in the early 1950s as the dominant departmental theory and method, did not evolve out of philology; rather it represented a sharp rejection both of philology's theory and its method. Few early English-department publications are still read today; philology, as it was practiced and taught in American universities for some fifty years, has been so completely erased from departmental memory that precisely what American philologists did and why they did it seems to have been largely forgotten.

In recent decades, there have been occasional calls for a return to philology, most notably Paul de Man's "The Return to Philology" (in his The Resistance to Theory, 1986), Edward Said's “The Return to Philology" (in his posthumous volume Humanism and Democratic Criticism, 2004) and Michael Holquist's "Why We Should Remember Philology" (2002). These calls for a 
return, as Geoffrey Harpham has recently noted, typically invoke a favored version of philology, ignore most of the actual history of philological study, and sidestep the dangers involved in any such return. Harpham, however, focusses primarily on the more speculative aspects of philological theorizing and ignores the extent to which linguistic philologists, at least, had by the mid nineteenth century largely given up on such theorizing. More surprisingly, he asserts, contrary to the evidence readily available in first five or six decades of $P M L A$, $M L N$ and Modern Philology, that "philology had been unable to establish itself as an academic discipline in the American research universities taking shape at the end of the nineteenth century" (Harpham, 2009: 50). This paper aims to demonstrate that both the modern American university and its newly invented modern-language departments were derived in large part from German models. It aims as well to show precisely what professors in the early English departments borrowed from German philological theory and how they used its methodological apparatus to generate decades of specialized departmental research.

\section{The Modern American University and the German}

\section{Academic Model}

The modern American university emerged shortly after the Civil War and was in many of its essentials based directly on the contemporary German university model. The traditional American college had, from the founding of Harvard in 1636 until the late 1860s, remained largely unchanged both in its organization and in its orientations: its curriculum was almost entirely prescribed and was focused largely on Greek and Latin studies; its pedagogic method involved little more than rote memorization and in-class recitation. ${ }^{2}$ Few instructors possessed specialized knowledge, nor was it expected of them; libraries were miniscule; few provisions were made for advanced studies. Shortly after the Civil War, American educational reformers set about transforming the traditional academic system. The changes occurred rapidly, though not everywhere at the same pace: at some institutions, the reforms were effected by the mid 1870s; at almost all others, by the early to mid 1880 s. $^{3}$ Harvard's President Charles William Eliot successfully demonstrated that a traditional college could be transformed into a modern university; other reformers, including Cornell's Andrew D. White, Johns Hopkins' Daniel Coit Gilman, Stanford's David Starr Jordan and Chicago's William Rainey Harper, inspired newly wealthy entrepreneurs and industrialists to donate vast sums for

\footnotetext{
${ }^{2}$ For an extended analysis of the traditional American college, see Paulsen, 2013: passim.

${ }^{3}$ The most incisive commentaries on the forces that shaped the new academic system come from the leading educational reformers of the day: see Eliot, 1898: passim; Gilman, 1906: ch. 1; and White 1905: chs. 17 and 19.
} 
the establishment of new, entirely modern universities. The reformers' principal aim was to create an academic system which could respond directly to the evolving scientific, technological, managerial and social needs of a rapidly industrializing nation. Whereas the traditional American college had aimed to preserve traditional knowledge and to transmit genteel literary culture and elitist social attitudes, the new academic system was designed to promote specialized research and teaching in all departments of knowledge and to fit young people for an ever expanding set of specialized occupations.

When devising the new system, reformers turned to the contemporary German university. The academic systems in France and England were still primarily devoted, in their different ways, to producing gentlemanly scholars and to preparing elite students for their social roles (Hart, 1874: 321-28; Thwing, 1906: 6). In contrast, the German university focused on the production and transmission of specialized scholarly and scientific investigation, a focus which attracted thousands of American students to Berlin, Halle, Heidelberg, Göttingen, Leipzig, Munich and Freiburg in and after the mid nineteenth century (Thwing, 1928: 40-45, Herbst, 1965: 1-2). Instead of a prescribed curriculum, the German university had an elective system that offered nearly complete freedom of choice in coursework; instead of a narrow, general curriculum, there was a wide-ranging, specialized curriculum that gave students access to the findings of diverse sets of experts; instead of rote and recitation, there were lectures and, at advanced levels, seminars. Led by Harvard's President Eliot, American higher educational institutions rapidly replaced prescribed classwork with German-style free elective courses, thus permitting American students for the first time to shape as they wished the greater part of their undergraduate program. ${ }^{4}$ Led by Andrew D. White, who guided Cornell into existence in 1868, educational institutions rapidly expanded the narrow traditional curriculum to incorporate a vast array of specialized scientific, technical and vocational studies (offering a far wider curricular array than German universities, where vocational and utilitarian studies were typically shunned), thus permitting American students to receive training in almost any subject they desired, the only conditions being that the subject could be systematically taught and that it was in sufficient demand (Gilman, 1906: 18; White, 1869-70: 23).

4 University presidents soon discovered, however, that in a largely free-elective undergraduate system, students frequently scattered their elective choices too widely or concentrated them too narrowly. Just after the turn of the century, presidents and other administrators fashioned the concentration-distribution undergraduate system, which required students to "distribute" a certain number of electives in several of the main divisions of knowledge and to "concentrate" a certain number in one particular discipline (their "major"). This was the last major innovation in the modern academic system and, like the other innovations, it still prevails today. 
In the eyes of the educational reformers of the 1860s and 1870s, perhaps the most glaring defect of the traditional college was its failure to promote scholarly and scientific investigation. The contemporary German university, in contrast, promoted the elaboration of systematic disciplinary theories, the development of rigorous methodologies, and the painstaking application of theory and method to narrowly defined research topics, all with the aim of carrying knowledge irreversibly forward. In addition, since the late eighteenth century, German academics had, in an effort to extend Newton's successes to other disciplines, offered to put all subject matters, even nonscientific ones such as theology and literature, onto a scientific footing, motivated by the belief that, since man was part of nature, all things pertaining to man must be susceptible to scientific study, if not by experimental methods, then by other, perhaps equally scientific, methods (Bolter, 1980: 90-93). American educational reformers recognized that, by imitating the German university's efforts to apply scientific theory and method to all fields of inquiry, they could construct an academic system that not only supplied the growing industrial economy with scientific, technical and managerial experts, but might also make possible the creation of a nonpartisan professional class capable of employing scientific ideas to produce principles for rational social progress (Bledstein, 1976: 321, 326).

The German conception of research and research training received its strongest impetus when Johns Hopkins opened in 1876. Hopkins' President Gilman established a full-fledged graduate program with systematic training in diverse disciplines and with systematic rules for acquiring advanced degrees: as in Germany, doctoral students were taught through seminars and were required to engage in original research culminating in the production of an extended dissertation. Other universities quickly followed suit. In the graduate schools, future researchers were imbued with the new scholarly ethos, borrowed from the German university, which dictated that the researcher's main aim should be to advance knowledge instead of preserving it and that the only way knowledge could be properly advanced was through the production of scientifically objective, technically expert and narrowly focused research. By the 1880s, the American graduate school of arts and sciences, with its extensive facilities for scientific research and for advanced scholarship, had become the central component of the newly founded universities and the transformed traditional colleges. At first, many institutions continued to employ a few instructors of the older, unspecialized variety, but as soon as American graduate programs began churning out significant numbers of specialized researchers in every department of knowledge, such instructors all but disappeared except at minor institutions. At most institutions, as the yearly academic catalogs testify, the doctorate had become, well before the turn of the century, the standard requirement for academic appointments (see James, 1911: 334- 337). 
In domesticating the German academic model, American educational reformers made substantial revisions both to the academic career structure and to the institutional organization of academic research and teaching. In the modern American university, instructors were, as in Germany, now typically hired on the basis of their possession of a doctorate, which provided evidence not only of specialized expertise but also of professional research competence; as in Germany, they were obliged, if they were to retain their positions, to engage in the continual advancement of knowledge through the publication of specialized articles, monographs or editions. In the German university, however, the research career was distinctly hierarchical and narrowly meritocratic. In each German university, a single senior professor, usually appointed to his chair by the state, controlled the entire discipline and "both privately trained and personally determined the fate of the apprentice academic who aspired to a university position" (Bledstein, 1976: 314). Junior instructors in Germany were poorly paid and were forced to rely on the good will of senior professors. Under such conditions, the pursuit of knowledge was sometimes marked as much by resentment and deference as it was by freedom (T. Dwight, 1903: 228-29). In post-Jacksonian America, such a system would have been offensive to the national sensibility. Responding to the vocational and professional aims of the middle-class Americans who had quickly come to dominate the student body and professoriate, American educational reformers devised an academic career structure which, unlike the German career in research, was notable for its egalitarianism and its institutionalized regularity. Various grades existed within the American academic profession, but all instructors were called professors, and all had access to a regular system of promotions up through the various grades. In Germany, specialized academic "research was regarded as a creative act-a higher calling - not a professional career for which one was paid money" (Bledstein, 1976: 314). In America, by contrast, research was made into a regularized and fully professionalized career (Veysey, 1965: 317-24, 381-418). In the early modern university, American professors utilized this career structure to create a series of highly specialized and highly differentiated academic professions, the profession of English being just one among many.

The departmental organization of academic knowledge was also an American innovation. In the traditional American college, there had been little need for separate academic departments since instructors had not been numerous, nor usually very specialized in their focus, and the college's aim had not been to advance specialized knowledge. Nor did the nineteenth-century German university have departments: academic knowledge was organized into large disciplines (philology being one of the principal ones) and into various institutes, each presided over by a senior faculty member. Again, Daniel Coit Gilman led the way: when setting up John Hopkins, he systematically organized 
all research and teaching activities into separate, largely autonomous departments and gave each department equal institutional status. Other universities quickly imitated the Hopkins model. By the late 1870s, the departmental system was so well established that newer and older institutions had almost without exception adopted it. Departments devoted to classical and modern literatures were created as a part of the same gesture which brought a myriad of other academic departments into existence. Already by the early 1880s, the English department had, together with numerous other departments, become a standard component of the modern university. ${ }^{5}$

\section{The Early English Department and German Philology}

Though educational reformers directly imitated the German academic model when constructing the modern American university, they also as we have seen significantly revised it: first, they democratized the curriculum by placing all subject matters, including vocational and utilitarian subject matters, on equal footing; second, they democratized academic knowledge by housing disciplinary subject matters in separate departments with equal institutional status; third, they democratized the academic profession by creating a graded, meritocratic career structure. The scholars who populated early English departments also directly imitated German models: they took over from German philology a ready-made theory, methodology and pedagogy; rather surprisingly, they made few if any substantial revisions to what they borrowed.

In the 1870 s and $1880 \mathrm{~s}$, when reforming presidents sought out scholars to establish and organize departments of English, they turned to the young American philologists who were then returning in some numbers from German universities, scholars who were committed to the new, scientific conceptions of knowledge and of academic competence (Thwing, 1928: 44-45). At a time when presidents and administrators were loath to grant academic status to subjects whose utility or whose susceptibility to scientific method could not be readily demonstrated, philologists succeeded in winning a secure place for literary studies. They did so by adhering to the modern university's narrowly technical conception of scholarly competence and by offering to investigate language and literature in a rigorously scientific fashion. In the early years of English departments, perhaps right through to the end of the 1880s, there was, as one leading philologist conceded, a certain amount going on that was not strictly philological (Cook, 1906: 50-51). Yet, as Arthur Applebee has recently noted, it was primarily as a result of the scientific "sanction of philology" that

\footnotetext{
${ }^{5}$ At many institutions, English often had at first to share the same department with other related subjects (usually other Teutonic languages), but this only lasted until enough money was found to set up a separate English department complete with its own specialists (see Garland, 1891: 3-4).
} 
"the teaching of literature spread quickly through the American college and university system" (Applebee, 1974: 27).

Johns Hopkins, which opened its doors in 1876, was the first higher educational institution to establish a full-fledged, coherently organized, English department. The success of Hopkins' philological modern-language departments spurred on the establishment of such departments elsewhere. As one contemporary scholar observed, it would be difficult "to overestimate the influence of this University in giving full academic recognition to the Modern Languages, in stimulating research by basing it on purely scientific methods, and in bringing about a more enlightened attitude toward these languages in other centers of learning" (Smith, 1899: 252-53). Hopkins gave impetus to the "ideals of specialization, of productive scholarship and of scientific study of the modern languages" and "established the first model for the training of teachers in English; up to that point there had been no standards in preparation at all" (Applebee, 1974: 27).

At Harvard, Yale, Columbia, Princeton and other long-established institutions, the old rhetorical tradition continued to vie for place, as did the impressionistic approach pioneered in the mid-century by Harvard's Henry Wadsworth Longfellow and James Russell Lowell. By the late 1870s, however, both these approaches had lost ground and, after the establishment of Hopkins' philologically oriented language departments, they lost even more ground. Given the immediate, wide renown of the language departments at Johns Hopkins, other institutions had little choice but to compete by hiring more philologists and by establishing systematic graduate programs to train students interested in careers in philological research. As Riley Parker notes, graduate training "on the Johns Hopkins pattern meant rigorous training in linguistics and textual analysis," with "little or nothing beyond seventeenth-century English literature," for the focus was on the "accepted need of mastering Anglo-Saxon, Middle English, old and modern French, old and modern German, and, preferably, several other Germanic languages or dialects" (Parker, 1967: 346) Parker concludes that the strongly "linguistic emphasis of graduate training at Johns Hopkins - and subsequently at Harvard, Yale, and elsewhere-was to produce, during the next fifty years in America, a completely new kind of English professor"-namely, the philologist (346-47).

In 1883, American philologists felt confident enough to establish their own specialized professional organization, the Modern Language Association. The association started with only 39 members, but expanded so rapidly that by 1899 it had around 500 members (Smith, 1899: 253). Before the association's founding, "scientific research, with few exceptions, was practically unknown" but the MLA quickly "united and consolidated the Modern Language forces" (Smith, 1899: 254). Literary scholars were now producing articles and editions at a pace which would have been unimaginable before the educational reforms 
of the 1870s. The dissemination of their specialized research results was facilitated by the creation of a spate of professional journals, most notably Publications of the Modern Language Association (founded in 1884), Modern Language Notes (1886), Journal of English and German Philology (1897) and Modern Philology (1903). By 1910, publications had become so extensive that they began to be charted yearly in American Year Book. After the demise of the Year Book in 1920, PMLA took over with its yearly "American Bibliography."

Philology dominated literature departments in America from their establishment in the 1870s and 1880s until at least the 1920s; in a somewhat diluted and less theoretically rigorous form known as literary history, it continued to dominate literature departments until the late 1940s. It is not particularly difficult to ascertain precisely what kind of research was produced by professors in the early decades of English departments, nor what kind of knowledge was transmitted to undergraduate and graduate students: these matters can be determined, as has been done below, by examining early departmental publications and early university catalogs. What remains less obvious is precisely what motivated English-department professors to accept the authority German philology so completely that, for some five or six decades, they not only retained their allegiance to it, but did so without substantially revising its theoretical apparatus or methodological practices. ${ }^{6}$ No doubt the institutionalization of philology in American modern-language departments (that is, the organization of departmental research and teaching around its principles) rendered it immune to rapid obsolescence. Yet, the continued allegiance of mainstream literary scholars to philology, even after its theoretical claims and its methodological practices had been substantially diluted in and after the 1920s, cannot be fully understood without taking into account the extraordinary prestige enjoyed by German philology in the nineteenth and early twentieth century, a prestige deriving on the one hand from its investigative successes and on the other from its sophisticated theoretical and methodological apparatus, which seemed to provide the means to study civilization in a comprehensive, scientific fashion. For the most part, American philologists took for granted the authority of German philology and simply set about using it to produce empirical research results and practical, fact-oriented, coursework.

\section{Linguistic Philology in Germany}

In nineteenth-century German universities, philology existed in two different but related forms, one of which focused largely on linguistic matters (and on such social and cultural matters as could be inferred from linguistic investigation), while the other focused more directly on the diverse aspects of

${ }^{6}$ With the exception of a few figures, such as the comparativist William Dwight Whitney, American philologists contributed remarkably little to philological theory or method. 
literary and cultural history. American literary academics borrowed and utilized both forms of philology. They relied primarily on linguistic philology until the turn of the century, focusing on the linguistic issues delineated by German linguistic philologists. After the turn of the century, their focus shifted to literature and to the hermeneutic approaches delineated by German cultural philologists, including the investigation of sources and parallels, stylistic attributes, and generic matters.

Linguistic philology, the branch of philology which dominated American English departments from the 1870s until around 1900, was based on philosophical principles outlined in the 1770s by Johann Herder (1744-1803) and then fleshed out at the turn of the century by Friedrich Schlegel (17721829) and Wilhelm von Humboldt (1767-1835). In some respects, linguistic philology was a revision of the classical philology which emerged in the Renaissance. Yet, there was a sharp contrast as well, for classical philology, as it was practiced in and after the Renaissance, had paid little attention to the "inner fabric of language" and even less to "historical changes," for its focus had been on etymology, "syntax," and "literary spirit" (Grimm, 1851: 2-3). This focus had, however, been partly inevitable since philologists from the time of Erasmus, Reuchlin, Scaliger and Casaubon to the time of Bentley and Porson had been "almost wholly occupied in disentombing old authors...or in filing away excrescences and corruptions from the text, as first obtained, by a more careful collation of manuscripts" (B. Dwight, 1864: 196-97). ${ }^{7}$

Linguistic philology, as elaborated by German philosophers in the late eighteenth century, was far more ambitious in scope than classical philology. In a seminal work entitled Über den Ursprung der Sprache (1770), Johann Herder set out the central theoretical positions of the new philology. First, Herder rejected any divine origin for language (Herder, 1965: 149). Second, he dismissed the materialist conception of language maintained by Locke, Condillac and Horne Tooke, who argued that words and their meanings were arbitrarily connected and that, therefore, language was an arbitrary construct $(92,94,119-20,132-42,151,158)$. In Herder's view, language could not be merely accidental, for it was "as essential to man as it is essential that he is a man." Man was not simply an "instinctual animal" but a "creature of reflection" whose innate power to reflect had enabled him to "invent language" by recognizing in things their "essential" or "distinguishing mark" and by naming things according to that mark $(108,112,115,117)$. Third, Herder posited that language, like culture in general, was subject to historical change, thus rejecting Condillac and Tooke's notion that all languages formed a unity and that they all possessed a common or "universal" structure arising from the naming, in verbs and nouns, of simple sensations (Harris and Taylor, 1997: 67-

${ }^{7}$ As is shown below, the emphasis on textual analysis and the creation of "critical editions" remained in the other version of modern philology, cultural philology. 
69). For Condillac and Tooke, the differences between languages were superficial, for they were simply the result of the subsequent development of diverse shorthands for words describing simple sensations. Herder, however, argued that language had multiple origins, that these origins had to be firmly placed within history, and that each subsequent language had to be studied in the context of the specific historical pressures that had acted upon it. Most importantly, each language was a Volksstimme, that is, the outward expression of a "nation's culture and the specific character of its thinking" (Herder, 1965: 149; also Dowling, 1986: 9, 15). Given this, it seemed evident to Herder that the study of "the art of speech...down through the generations and down its stages" would gradually produce a complete history of the "progression of the human mind" $(162,163)$. Fourth, Herder proposed that languages were, in their earlier stages, more sensuously immediate, more directly connected to the world, since the earliest words originated either in imitations of sounds or, more often, in attempts to discern the essential quality of the emotions caused by certain images; consequently, "the analogy of the senses [was still] noticeable." Later language was more abstract, for words which were once harmoniously connected gradually became unknitted as these words took on new, nonphysical meanings and became related to each other in new ways (148-49, 15152). While Herder did not ignore the later stages of linguistic (and, by extension, cultural) evolution, all of which left abundant "traces of the development of the human mind" (162), he suggested that the study of the earlier, more sensuously immediate stages was vitally important, for it made modern man conscious of periods of cultural history when human beings were more spiritually whole.

The next two generations of philologists followed Herder in elevating linguistic history into the history of national cultures and of human culture in general (Jankowsky, 1972: 38). Furthermore, their scholarly focus was directly shaped, first, by Herder's contention that linguistic structures were "specifically national" and thus entirely "in conformity with the manner of thinking and seeing of the people, of the inventor, in a particular country, at a particular time, under particular circumstances" and, second, by his emphasis on the initial linguistic periods, the "deepest depths of language" (Herder 1965: 157, 150). For them, as for Herder, the study of language led not only to an understanding of the spiritual essence of specific peoples at specific times, but also to an understanding of the spiritual essence of the human animal. William von Humboldt and Friedrich Schlegel further clarified the philosophical grounds of the new philology. Schlegel's Über die Sprache und Weisheit der Indier: Ein Beitrag zur Begründung der Altertumskunde (1808) was of particular importance for language studies in and beyond Germany, for it set out the aims and principles of the new discipline of comparative philology, providing it with a useable methodology and outlining its principal research tasks. Schlegel 
argued that comparisons between languages should not be based, as earlier scholars had supposed, on lexical correspondence, but rather on grammatical correspondence (including the correspondence of grammatical relations expressed in inflections). Instead of attempting to prove genealogical connections between languages by comparing lexical elements and by compiling lists of similar words (which might merely be false relatives), the proper method was to prove these connections by comparing grammatical structures and by uncovering grammatical affinities, such as " tvon" in Sanskrit and " thum" in German, which were both used to create nouns referring to creative power (Schlegel, 1849: bk. 1, ch. 3). Schlegel also fleshed out Herder's contention that earlier languages were more harmonious and sensuously immediate by showing that in Sanskrit, one of the earliest of extant European languages, all parts of speech (from verbs to nouns to adjectives) were internally derived "from the roots" and thus bore "the stamp of affinity, all being connected in their simultaneous growth and development by community of origin" (449). For Schlegel, Sanskrit's linguistic organicity, unlike the linguistic heterogeneity of modern European languages, was conducive to spiritual wholeness and sensuous simplicity: it permitted expression of "a peculiarly fine feeling of the separate value and appropriate meaning...of the radical [root] words or syllables." This gave the language a "lofty spirituality" but made it, "at the same time, extremely simple" $(429,445,457)$.

In sum, Herder, together with Humboldt and Schlegel, elaborated not only the main theoretical principles of modern linguistic philology, but also its central methodological practices and its basic research problems. For them, however, philology was only one part of a much larger literary and philosophical battle against the Enlightenment concepts of universally applicable rational principles and of indefinitely continuing social and cultural progress. Like other founders of the romantic school, they opposed the acceptance of classical culture as the ultimate authority, that is, as the purest source of rational principle, artistic style and wisdom (Amsterdamska, 1987: 36-38). Similarly, they opposed the notion that societies progressed toward higher forms, culminating in a cultural apex, as it was supposed Greece and Rome had. Instead they argued that the earlier stages of societies were in many respects superior to their later, supposedly more advanced, stages. With their romantic animus against stultifying classical and pseudo-classical authority and with their high valuation of early, seemingly uncorrupted, indigenous culture, Herder, Humboldt and Schlegel supplied the philosophical motivations that inspired generations of extraordinarily industrious investigators of language. The most notable second-generation figures were Jakob Grimm (1785-1863), lexicographer, founder of Germanic philology and folklore compiler, and two pioneering comparativists, Franz Bopp (1791-1867) and Rasmus Rask (1787-1832), who demonstrated the connections, respectively, 
between the most remote Indo-European languages and between the most remote Teutonic languages. Their methodology, derived directly from Schlegel's practice of demonstrating genealogical relations through the identity or comparability of structural features, primarily involved systematic inflectional comparison (Jankowsky, 1972: 156; Pederson, 1962: 241). Yet, they applied their methodology with such rigor and sophistication that their scholarship attracted admiration throughout Europe and beyond. In Germany, their ideas were rapidly institutionalized in universities, a process made easier by the fact that their conceptions of research and teaching were in complete harmony with the new ideal of learning promoted by German neohumanists, who were then in the process of transforming the German academic system. The neohumanists, among whom Wilhelm von Humboldt figured prominently, believed that the university should not be focused on "the acquisition of a certain technical ability or craft, nor...pragmatic professional pursuits," as the newly reformed French system was, but rather on the "formation of a whole and spiritually rich individual who, thanks to his education, would be prepared to serve the nation and the state." The neohumanists' goal was to redesign German higher education so that it could "promote the integral and free cultivation (Bildung) of the individual and his talents," with knowledge not being "imposed from the outside, but...achieved as a result of inner need and self-motivated research" (Amsterdamska, 1987: 66-67). Their conception of higher education, which was put in place by the rapid reform of existing universities and by the establishment of Berlin University in 1810, promoted specialized scientific research and specialized coursework in all branches of knowledge.

While early modern-language professors in America borrowed their focus on grammatical and morphological matters from first- and secondgeneration figures such as Herder, Schlegel, Bopp and Grimm, their brashly positivistic faith in the scientificity of their investigations, as well as their interest in phonology, primarily came from later groups of German philologists. At first, German philologists focused, as we have seen, on the reconstruction of the earliest stages of Indo-European languages and, more tentatively, of the proto-language from which the later languages appeared to have descended. Yet, as they sought to uncover the original, "purest" forms of root words, philologists also began to discover regular patterns in the ways that root words changed as they were passed down (Jankowsky, 1972: 58). By the mid-century, there emerged among younger philologists an increasingly strong conviction that sound laws could be discovered to explain most, if not all, of the changes in root words that occurred as these were passed down from the parent language, or passed from one language into a neighboring language, or passed down in altered form within the same language. Led by August Schleicher (1821-68) and Wilhelm Scherer (1841-1886), the third generation of linguistic philologists 
vigorously set about discovering further laws of linguistic development, arguing that the evolutionary processes that affected language were entirely analogous to the evolutionary processes that affected plants, animals and inanimate nature and were thus just as susceptible to scientific analysis as were natural processes. A fourth generation of philologists, who came to prominence in the 1860s and 1870s and were known as the Junggrammatiker (and, in English, as the neogrammarians), objected that biological mutations might display a directionality leading from lower to higher forms, but linguistic mutations did not appear to follow any such trajectory (Sampson, 1985: 21). Yet, while the neogrammarians rejected Schleicher's biologism, they promoted an even more thoroughgoing positivism, sometimes proclaiming (as even Schleicher had not) that there were no possible exceptions from the regularities of the sound laws (Pederson, 1962: 242-43; Jankowsky, 1972: 132).

Satisfied of the enduring scientific value of their investigations, German philologists compiled ever greater stocks of data in their effort to discover and verify the laws that appeared to govern all aspects of linguistic evolution and, that, presumably, also governed all aspects of cultural and literary evolution. They did in fact make enormous contributions to the understanding of language, contributions upon which later linguistic schools were built. For the most part, however, linguistic philologists in Germany, like those who followed in their footsteps in America, paid little attention to cultural and historical matters and, even when they did, their successes in discussing intellectual conditions or cultural products were at best debatable. By the mid-century, there were few if any serious attempts to make good on Herder's motivating idea that linguistic history could be used for the systematic reconstruction of cultural history, especially its earlier stages.

\section{Cultural Philology in Germany: The Four Hermeneutics and Their Methodologies}

The young Americans who received advanced training in linguistics and literature in Germany during the last four decades of the nineteenth century also came into contact with another, more expansive, philological tradition, that is, cultural philology. While linguistic philology had after the mid-century moved some distance from its early emphasis on culture and history, cultural philology continued to be centered on the recuperation of the historical, social and cultural aspects of literary and other texts. Nevertheless, the two branches of modern philology co-existed in relative harmony, largely because they were both grounded in late eighteenth-century romantic theories of culture. Both branches resulted from scholars' efforts to change the focus of philology from the collation and criticism of manuscripts to the investigation of the history of civilization. Herder, Humboldt and Schlegel transformed philology by employing comparative linguistic analysis as a tool for tracing human communication through its various paths and bypaths. The founders of cultural 
philology, most of whom were classics professors, transformed philology in another direction, by expanding it to cover the study of diverse cultural manifestations. But both branches of modern philology presupposed that there existed in each culture, during each period of its history, a central essence that pervaded and unified all of its products (Jankowski, 1972: 94-95).

The main figures in the creation of cultural philology were Friedrich August Wolf (1759-1824), who taught at Göttingen then at Halle, and August Boeckh (1785-1867), who studied under Wolf at Halle and then taught at Heidelberg and Berlin. Boeckh's influence was particularly pervasive: his lecture series on philology, which he offered twenty-five times during his fiftysix year career at Berlin (1811-67), provided several generations of scholars with the theoretical justifications and the methodological tools for engaging in cultural philological investigation. After his death, Boeckh's lectures were published as the Encyclopaedie und Methodologie der philologischen Wissenschaften (1877; 2nd ed., 1886). The authority that this work attained, not only in Europe but also in America, can hardly be exaggerated. When American literary academics shifted their focus at the turn of the century from linguistic philology to cultural philology, Boeckh's Encyclopaedie provided them not only with the conceptual grounding for their revised approach, but also with the specific methods they employed in their investigations. In fact, as we shall see, most of what went on in English departments during the first two decades of the twentieth century can be seen as issuing more or less directly from the theoretical and methodological approaches summed up in Boeckh's text. Even after American scholars began, in the 1920s, to ignore cultural philology's grander aims, they continued right up into the 1940s and 1950s to employ the research methodology sanctioned by Boeckh.

In the Encyclopaedie, Boeckh defined philology as a comprehensive science of civilization, "the understanding of what has been produced by the human spirit, the understanding of what is known" (Boeckh, 1968: 8). Philology's aim was to recuperate the history of each nation by reconstructing "the entire mental development, the history of all aspects of its culture" (39). In so doing, it would also discover, in each nation's diverse cultural products, "an inner essence, an image" that "is stamped in all of it" (38). The project of cultural philology, that of reconstructing the "totality of knowledge," necessarily incorporated a vast range of "special sciences" focused on specific aspects of a nation's culture - from its legal system and civil institutions to its scientific conceptions and its literary productions (17). Yet, philologists did not need to fear that their narrowly specialized investigations would lead to fragmentary knowledge for philological theory provided an "over-all scientific interrelation of that which one has grasped as particular" (34). Since all philological specializations were organically related through their focus on the 
unfolding of inner essences, every specialization "leads back to the center and proceeds in all directions from this center toward the periphery" (33).

Boeckh divided philology into two parts: hermeneutics, which involved the interpretation of texts, and textual criticism, which involved the reconstruction of the purest possible text. He further subdivided both hermeneutics and textual criticism into four interrelated parts: grammatical, historical, individual and generic. Though Boeckh accorded equal space in his Encyclopaedie to hermeneutics and textual criticism, he gave priority to hermeneutics, as did most subsequent cultural philologists in Germany and in America. Textual criticism was primarily concerned with restoring the author's original text by employing historical, biographical and other evidence; it properly resulted in the publication of a "critical edition." Hermeneutics, however, offered to establish the total social and cultural context of a given work or historical period.

Of the four hermeneutics, German cultural philologists viewed grammatical or lexical interpretation as the most "fundamental" because it involved explication of "the literal meaning of the words" (51). This hermeneutic required scholars to apply their historical knowledge of a language to the grammatical explication of every passage. Yet, it also required them to confirm their interpretation by employing a specific hermeneutic method, that of compiling lists of parallel passages and source passages. Certainty of understanding, Boeckh argued, could only be arrived at by basing the explication "of every passage of a literary work...upon parallel passages," by compiling "citations...from others as evidence for the grammatical interpretation of a writer or thinker" $(66,67)$.

The second hermeneutic, historical interpretation, involved understanding "the meaning of the words in reference to the material relations and context of the work." Historical interpretation was necessary because the meaning of a passage "consists partly in ideas which do not lie in the words themselves, but are bound up with their objective sense by their references to actual conditions" $(51,77)$. For historical interpretation, "there is a sliding scale of applicability according to the individuality of the author and the literary genre," that is, according to the amount of historical context that is presupposed by an individual writer or a specific genre (78). To engage in historical interpretation, what the scholar needed was a profound knowledge both of general history and of the history of the period in which a given work was written. Again, however, the philologist had to employ a specific hermeneutic method, involving the compilation of "general and special factual lexica" and of "a great number of apposite citations," since the "practice of extremely accurate citation is a genuinely philological activity, for philology rests upon bits of external evidence" (86-87). 
The third hermeneutic, individual interpretation, involved the examination of a writer's specific use of language in order to ascertain to what extent the words of a text were "invested with additional, peculiar meanings" (51). Such interpretation required the scholar to analyze the writer's "special manner of thinking and point of view, which are grounded in the reciprocal relation of his mental and spiritual powers...This is his individuality. It manifests itself in every aspect of his being; it abides equally in word and deed and every feeling" (90). Furthermore, the "individual style" was rooted in the "national style," though it "branches off from the national with greater or less personal characteristics" (90). To engage in individual interpretation, the scholar needed to possess a comprehensive knowledge of the writer's work and life. The specific hermeneutic method applicable to individual interpretation was, once again, the compilation of lists, this time of lists classifying the diverse aspects of the writer's style. Instead of being satisfied with "abstract designations of style [such] as short, comprehensive, periodical or not, rich in articles or not," the scholar needed to make copious descriptive notes and copious classifications in order to define the writer's style and to move from there to engage in accurate individual interpretation of a given passage or text (102).

The fourth hermeneutic, generic interpretation, required scholars to examine the extent to which the meanings of words were affected by the writer's desire to conform to the rules of a specific genre (51). It was "not possible to establish a canon of applicability for...generic interpretation," for its importance depended, as did that of historical and individual interpretation, on the specific case at hand (107). Nevertheless, scholars had to possess a detailed knowledge of each genre's specific functions in order to grasp a writer's reasons for employing a particular genre and in order to comprehend the writer's goal or "end," which invariably "imprints the character of the genre upon the unity of the work itself” (111). Since a genre's functions might change over time, accurate generic interpretation obliged scholars not only to examine the writer's work in itself, but also in its relation to "the history of his literary genre through all the ages of his nation" (108).

To fully interpret any given passage or text, the cultural philologist clearly needed to possess, or have at hand, an immense amount of factual data. As Boeckh put it, "to evaluate all the motives of a work, it is often necessary to consult the whole history of a nation" (108). Moreover, the four modes of interpretation were so intimately connected that the scholar could not meaningfully engage even in basic grammatical interpretation without having a thorough knowledge not only of the language in which a work was written, but also of the historical period when it was written, of the writer's life, oeuvre and style, and of the history of the genre employed by the writer (51-52). In practice, of course, cultural philologists in Germany did not always, or even 
typically, proceed very far toward comprehensive hermeneutic interpretation. Many of them expended their entire energy simply in producing preinterpretative data, that is, the grammatical, linguistic, historical, biographical, stylistic and generic data that, presumably, needed to be compiled prior to serious engagement in hermeneutics. ${ }^{8}$ Nonetheless, since academic training and scholarship in Germany were organized along broad disciplinary lines, scholars there were likely to feel at least some pressure to proceed beyond mere compilation. In the modern American university, where training and scholarship were narrowly departmental, the pressure to engage in broader scholarship or theorizing was much weaker.

\section{Linguistic Philology \\ 5. English Departments In The Late Nineteenth Century:}

Up to the turn of the century, German linguistic philology was the primary influence in American departments of English. Under the influence of this version of philology, early English professors prioritized the study of Anglo-Saxon and Middle English, stages of the language which presumably carried the inner essence of a whole people. In practice, this meant that while English professors often studied texts of some literary merit, these texts were studied mainly, and often exclusively, for their linguistic elements. What was true of research was equally true of teaching, especially in the graduate school. Johns Hopkins took the lead, focusing its graduate English program on "rigorous textual and linguistic study" and on the "mastery of the early languages - Old French, Old High German, Anglo-Saxon, and Middle English" (Applebee, 1974: 27). The model initiated at Hopkins spread rapidly to Harvard, Yale and other institutions (Parker, 1967: 346-47). Graduate theses were, in this pre-1900 period, mostly on linguistic matters. As John Manly later noted, "in early days the usual type of dissertation was a phonological or morphological study of the language of an Old or Middle English author" (Manly, 1912: xix). This fairly well characterizes most professorial productions as well. As for the undergraduate courses offered by early English departments, they were only slightly less linguistic in focus.

With the exception of book-length critical editions, most academic literary scholarship in the 1880s and 1890s took the form of articles in professional journals. The following articles, taken from random early volumes of PMLA, are representative of standard scholarly interests during the period when linguistic philology dominated: "Adjectival and Adverbial Relations; their Influence upon the Government of the Verb," "The Factitive in German," "The Genitive in Old French" (PMLA 1, 1884-85), "The Stressed Vowels in Aelfric's Homilies," "Notes on Elizabethan Prose," "The Impersonal Verb" (PMLA 4,

${ }^{8}$ See, for example, the articles in any early volume of Romania, Anglia, Englische Studien or Archiv, or the reviews of German monographs in early volumes of Modern Language Notes, Modern Philology and Journal of Germanic and English Philology. 
1888-89), "The Name Caedmon," "Dialectical Studies in West Virginia," (PMLA 6, 1891), "Warmpth," "Shakespeare's Present Indicative s-Endings with Plural Subjects: A Study of the Grammar of the First Folio" and "The Dialect of the Hildebrandslied" (PMLA 11, 1896). ${ }^{9}$ As is usually the case with linguistic philological studies, the titles of these articles fairly clearly lay out the entire scope of the subjects they cover. Literary works (if they were discussed at all) simply served as pretexts for linguistic investigation. They were treated as though they were merely linguistic formations, whose meanings could be best ascertained through grammatical, morphological, phonological and etymological analysis.

Departmental leaders such as Yale's Albert Cook steadfastly maintained, however, that the "study of language is essential...to the comprehension of literature" (Cook, 1898: 200). Thus, in his Higher Study of Literature, Cook devotes a central chapter to the "relation of words to literature." Yet, when he gets down to examining the specific relation of the word "gleam" to the meaning of Tennyson's Merlin and the Gleam, all he does is tabulate the uses of "gleam" and of similar words in Tennyson's oeuvre and, then, go on to trace the linguistic history of "gleam" from Anglo-Saxon forward (Cook, 1906: 78-86). What is worse, Cook's analysis of "gleam" seems almost entirely irrelevant, for Tennyson makes it abundantly clear in the poem itself that he is using "gleam" as a symbol for the poetic imagination. Neither in his lengthy discussion of "gleam" nor elsewhere in the book does Cook offer any evidence to demonstrate that the knowledge provided by linguistic philology is "essential" to the understanding of a literary work or even why it deserves more than the occasional footnote.

In sum, then, during the last quarter of the nineteenth century, the research coming out of English departments was primarily devoted to the accumulation of small linguistic facts. English professors appear to have had scant interest in utilizing their findings to theorize about linguistic, literary or cultural evolution; almost nothing of this sort can be found, even in PMLA. Rather, American literary scholars concentrated, far more single-mindedly than their German counterparts, on producing empirical, if rather trivial, data.

\section{Cultural Philology}

6. English Departments From The Turn Of The Century:

English-department graduate instruction and research were until the teens or early twenties primarily focused on Anglo-Saxon and Middle-English texts. After the turn of the century, however, most younger philologists and

\footnotetext{
9 The early volumes of Modern Language Notes, Modern Philology and Journal of English and German Philology were even more exclusively linguistic than PMLA in that they offered far fewer articles on the problems involved in teaching the modern languages and in securing their curricular position.
} 
many established scholars moved beyond a linguistic approach, either supplementing it, or more often supplanting it, with the hermeneutic approaches. Some conflict may have existed between scholars who continued to engage mostly in linguistic investigation and the majority who now turned their attention primarily to hermeneutic studies, but such matters do not seem to have been argued out at the theoretical level, at least not in any publications. It may be, however, that debates over the displacement of linguistic philology by cultural philology were deemed unnecessary since cultural philology still made room for linguistic analysis, if not as an end in itself (as it often had been), then at least as an aid to grammatical interpretation.

Whatever the case may be, linguistic studies declined so rapidly that, within a decade after the turn of the century, articles on linguistic matters represented less than a tenth of the work published in the leading professional journals. Hermeneutic investigations took their place. Judging from the publications listed in American Year Book and from the contents of the main professional journals, the vast majority of modern-language publications during the first two decades of the twentieth century fell into one of the four categories of hermeneutic study defined by German cultural philologists-grammatical, historical, individual and generic. Initially, scholars focused mostly on grammatical interpretation or, more precisely, on compiling the diverse data required for grammatical interpretation. Numerous departmental publications were devoted to lexical and grammatical compilations as these were deemed vital for the recovery of the precise meanings of words, phrases and idioms, and thus for the accurate interpretation of specific passages and entire texts. Articles on source passages and parallel passages also became a minor industry since such investigations were, in theory at least, necessary to aid the interpretation of each passage of a work and served as well to clarify the influence of one writer on another and the relationship between one version of a story and another. The following PMLA articles are typical pieces of sourcesand-parallels scholarship, the first two being the only examples in pre-1900 $P M L A$ volumes, while the remaining articles, drawn from random post-1900 $P M L A$ volumes, were published during the first two decades of the twentieth century, when the investigation of sources and parallels was the most prominent form of literary research in America: "On the Source of the Italian and English Idioms Meaning 'To Take Time by the Forelock"' (PMLA 8, 1893), "Spenser's Imitations from Ariosto" (PMLA 12, 1897), "The Literary Influence of Sterne in France," "The Relation of Shakespeare to Montaigne," "The Relations of Hamlet to Contemporary Revenge Plays" (PMLA 17, 1902), "Shakespeare's Julius Caesar in the Light of some other Versions," "Observations on the Origin of the Medieval Passion-Play," "Some Early Italian Parallels to the Locution The Sick Man of the East" (PMLA 25, 1910), "The Influence of Piers Plowman on the Macra Play of Mankind," "Influence des Récits de Voyages sur 
la Philosophie de J.J. Rousseau" (PMLA 26, 1911), "The Sources of Jonson's The Staple of News," and "A Possible Forerunner of the National Epic of France" (PMLA 30, 1915). Unfortunately, the material presented in such articles was most often presented simply as raw data. At best, a scholar would trace a literary passage back to its original source and perhaps show how its occurrence in various writers' works illustrated their different attitudes. Such investigations were, however, rarely used to contribute to the overall interpretation of a literary text much less to elucidate aspects of literary history or cultural evolution.

Slightly less attention was accorded, initially at least, to the second hermeneutic, historical interpretation. Following Boeckh's advice, English professors, like other modern-language professors, compiled "general and special factual lexica" (including concordances of individual writer's works) and at the same time churned out numerous pieces on historical references, composition dates and historical background. The following articles, the earliest being the only example of such scholarship in pre-1900 PMLA volumes, are typical pieces of historical interpretation: "The Christian Coloring in the Beowulf" (PMLA 12, 1897), "On the Date and Composition of The Old Law" (PMLA 17, 1902), "On the Date of King Lear" (PMLA 21, 1906), "Dryden's Conversion to the Roman Catholic Faith," "Four Obscure Allusions in Herder" (PMLA 22, 1907), "Browning and the Marathon Race," "The Staging of the Court Drama to 1595," "The Family of Maurice Scève" (PMLA 24, 1909), "The Date of Chaucer's Medea" (PMLA 25, 1910), "A Study in Renaissance Mysticism: Spenser's 'Fowre Hymnes"” (PMLA 26, 1911), "The Arrangement and Date of Shakespeare's Sonnets" and "The Siege of Troy in Elizabethan Literature" (PMLA 30, 1915).

American scholars who practiced the third hermeneutic, individual interpretation, usually followed Boeckh's advise in not focusing on psychological or biographical reconstruction but rather on the analysis of the ways that authors' styles pervaded all aspects of their writing (though in and after the 1920s, they largely abandoned such investigations in favor of accumulating biographical and diverse historical data). Articles on individual interpretation include "Triolus and Criseyde: a Study in Chaucer's Method of Narrative Construction" (PMLA 9, 1896), "A Study of the Metrical Structure of the Middle English Poem Pearl" (PMLA 12, 1897), "The Syntax of Antoine de la Sale," "The Detection of Personality in Literature" (PMLA 20, 1905), "Romantic Tendencies in the Novels of Abbé Prevost" and "Psychological Reasons for Lessing's Attitude toward Descriptive Poetry," (PMLA 26, 1911).

The fourth hermeneutic, generic interpretation, attracted less attention than the other three, but American philologists did nevertheless produce studies both of genres themselves and of specific examples of different genres. Early articles include "The Allegory as Employed by Spenser, Bunyan and Swift" 
(PMLA 4, 1888-89), "Pastoral Influence in the English Drama" (PMLA 12, 1897), "Literary Symbolism in France" (PMLA 18, 1903), "The Scansion of Prose Rhythm" (PMLA 20, 1905), "The English Fabliau" (PMLA 21, 1906), "Symbolism, Allegory and Autobiography in The Pearl" (PMLA 24, 1909), "The Place and Function of a Standard in a Genetic Theory of Literary Development" (PMLA 25, 1910), "The Pastoral Elegy and Milton's Lycidas" and "The Romance Lyric from the Standpoint of Antecedent Latin Documents" (PMLA 26, 1911).

In their hermeneutic studies, American philologists did not typically proceed to actual interpretation, except of the occasional short passage. Rather, their aim appears simply to have been the production of "objective," "scientific" data concerning sources, parallels, historical references, historical background, stylistic particularities, publication details, transmission details and the history of genres. Presumably, once published, the data could be used by other scholars for the purposes of interpretation, though for the most part it simply added to the stores of unused data.

\section{The Successes and Failures of Philology in Early English Departments}

Unlike the traditional rhetorical approach to English or the mid-century impressionistic approach pioneered by Longfellow and Lowell, philology was perfectly suited to meeting the strict criteria which the modern American university imposed on all academic departments. The theory of linguistic and literary evolution, which lay at the core of linguistic and cultural philology, posited an essential character not only for each national language and literature but also for each historical period of that language and literature. Philology thus supplied the conceptual apparatus necessary to elaborate a specific identity for the departmental subject matter and at the same time offered theoretical justifications for dividing the departmental subject matter into a series of presumably interrelated research fields and a rigorous methodology for investigating these fields.

The modern American university's emphasis on utility and science at first rendered literary studies rather suspect. As Princeton's Theodore Hunt wrote in the first PMLA volume, literature was, in the new academic environment, at times treated as if it were "a subject for the desultory reader in his leisure hours rather than an intellectual study for serious workers" (Hunt, 1884-85: 126). Philology, however, offered a means to demonstrate the utility of literary studies. As E.S. Sheldon noted in "Practical Philology," his MLA Presidential Address, philology provided the "sound linguistic training" which was "necessary" to "form the habit of close and accurate observation of apparently trifling things" (Sheldon, 1902: 103). Furthermore, philology offered the means to demonstrate the scientificity of literary studies. As Bryn Mawr's Carey Thomas noted, philology made sense of literary phenomena 
much "like evolution in science" (excerpted in Graff and Warner, 1989: 188). Hopkins' James Bright asserted that philology was succeeding, through "observation and inductive study," in establishing the laws involved in the "formula of modernity," the historical "laws" which caused "modernity" (Bright, 1903: lix, liii). Other scholars, opting for a rather less strident scientism, simply argued that philology was scientific because, like other scientific theories, it approached its subject matter as a "phenomenon," that is, as an objective "entity," a "manifestation of a general principle" (Hubbard, 1908: 256). The differences in view were minor, for American philologists agreed that, by applying philological methods to literary texts, they were slowly building up a solid edifice of scientific data about literature and culture, data which was just as important as scientific data about the natural world. And the progress of this science was of such import that, as one philologist put it, "when results are pretty safely established, we should make use of them. They may not have been generally accepted yet. We cannot always wait for that. We must keep abreast of the latest research and sift its results" (Brandt, 1884-85: 62).

While philology clearly facilitated the institutionalization of modernlanguage departments in the modern American university, what it did not do was make good on its claims to erect a solid edifice of scientific knowledge about literature and culture. In fact, few American philologists made any attempts to proceed beyond the accumulation of pre-interpretive data. Nor did philology even make good its claim to erect a solid understanding of individual literary works, since few philologists proved capable of proceeding through the various hermeneutics to actual interpretation. Furthermore, since philologists believed that they were promoting scientific standards of research and teaching, they felt obliged to dismiss and, insofar as possible, to banish unscientific practices such as aesthetic criticism. As W.E. Mead put it, "the personal element plays too large a part in [such] study for anything like accurate or scientific results to be obtained." Since the university was "a place for research, for scholarship, for finding out something hitherto unsuspected," there was no place in it for something so inherently subjective as "mere aesthetic theorizing" (Mead, 1901: xxi-xxii). Even philologists such as Calvin Thomas, who admitted that literary works had "an element of purpose" and consequently were not exactly like "natural phenomena," nevertheless downplayed aesthetic analysis, for such analysis offered "no objective test of rightness" (Thomas, 1897: 304, 306).

Yet perhaps philology's greatest failure was that it did not and could not supply any theoretical or methodological tools to prevent the research that it motivated from becoming routinized and compartmentalized. Philological theory justified the division of language and literary studies into separate periods and subperiods; it took for granted that these fields would always retain their essential interconnectedness and that even the most routine investigations 
would in time be fitted into the larger scheme of things. But what actually happened is that research fields became increasingly disconnected and compartmentalized. Unfortunately, even in and after the 1920s, when most mainstream literature scholars had given up on philology's larger aims of creating a scientific edifice of knowledge, they did not explicitly question philology's conceptual bases, theoretical aims or methodological directives. Instead, they simply supplemented its methods of linguistic and historical investigation with further methods for recuperating the historical contexts of literary works, though these methods often involved little more than the indiscriminate accumulation of any and all historical information concerning literary texts. Despite this, no new approach came near to dislodging the philological approach until the rise of New Criticism in the 1940s. Since then, few scholars, even among those who wish for a return to philology, have felt inclined to read through the vast piles of research publications accumulated during the decades when philology dominated English departments. Whereas the educational reformers of the 1860s and 1870s adapted the German university model to construct an academic system capable of evolving to meet America's changing social, scientific and managerial needs, the professors who organized the newly established English departments simply borrowed German philology wholesale, making few substantial revisions to it; when pressures for change came in the late 1940s and early 1950s, the philological model of departmental research and teaching was simply consigned to the dustheap.

\section{REFERENCES}

AMSTERDAMSKA, Olga (1987), Schools of Thought: The Development of Linguistics from Bopp to Saussure. Dordrecht: D. Reidel.

APPLEBEE, Arthur N (1974), Tradition and Reform in the Teaching of English: A History. Urbana, Illinois: National Council of Teachers of English.

BLEDSTEIN, Burton J. (1976), The Culture of Professionalism: The Middle Class and the Development of Higher Education in America. NY: Norton.

BOECKH, August Wilhelm (1968), On Interpretation and Criticism [Encyclopaedie und Methodologie der philologischen Wissenschaften (1877; 2nd ed., 1886)]. Trans. John Paul Pritchard. Norman: U of Oklahoma P.

BOLTER, Jay (1980), "Friedrich August Wolf and the Scientific Study of Antiquity." Greek, Roman and Byzantine Studies 21 (Spring 1980), 83-99.

BRANDT, H.C.G. (1884-85), "How Far Should Our Teaching and Text-books Have a Scientific Basis?" PMLA 1, 57-63.

BRIGHT, James W. (1903), "Concerning the Unwritten History of the Modern Language Association of America." MLA Presidential Address, Johns Hopkins, December 1902. PMLA 18, appendix, xli-lxii. 
COOK, Albert S. (1906), The Higher Study of Literature. Boston: Houghton, Mifflin.

COOK, Albert S. (1898) "The Province of English Philology." MLA Presidential Address, University of Pennsylvania, December 1897. PMLA 13, 185-204.

DOWLING, Linda (1986), Language and Decadence in the Victorian Fin de Siècle. Princeton: Princeton UP.

DWIGHT, Benjamin (1864), Modern Philology: Its Discoveries, History, and Influence. 3rd ed. NY: Charles Scribner.

DWIGHT, Timothy (1903), Memories of Yale Life and Men, 18451897. NY: Dodd, Mead.

ELIOT, Charles William (1898), Educational Reform. NY: Century.

GARLAND, Landon C. (1891), "[Chancellor of Vanderbilt's] Address of Welcome." PMLA 6, 3-4.

GILMAN, Daniel Coit (1906), The Launching of a University and Other Papers: A Sheaf of Remembrances. NY: Dodd, Mead.

GRAFF, Gerald and Michael WARNER, eds. (1989), The Origins of Literary Studies in America: A Documentary Anthology. NY: Routledge.

GRIMM, Jakob (1984), On the Origin of Language [Über den Ursprang den Sprache, 1851]. Trans. Raymond Wiley. Leiden: E. Brill.

HART, James Morgan (1874), German Universities: A Narrative of Personal Experience. NY: Putnam's.

HARPHAM, Geoffrey Galt (2009), "Roots, Races and the Return to Philology." Representations, 106.1 (Spring), 34-62

HERBST, Jurgen (1965), The German Historical School in American Scholarship: A Study in the Transfer of Culture. Ithaca: Cornell UP.

HARRIS, Roy and Talbot J. TAYLOR (1997), Landmarks in Linguistic Thought 1: The Western Tradition from Socrates to Saussure. 2nd ed. London: Routledge.

HERDER, Johann Gottfried (1966), Essay on the Origin of Language [Über den Ursprung der Sprache, 1770]. In On the Origin of Language: JohnJacques Rousseau, Essay on the Origin of Languages; Johann Gottfried Herder, Essay on the Origin of Language. Trans. John H. Moran and Alexander Gode. NY: Frederick Ungar.

HUBBARD, Frank Gaylord (1908), "The Undergraduate Curriculum in English Literature." PMLA 23, 254-68.

HUNT, Theodore W. (1884-85), "The Place of English in the College Curriculum." PMLA 1, 118-32.

JAMES, William (1911), "The Ph.D. Octopus." In his Memories and Studies. London/NY: Longman, Green. 329-347.

JANKOWSKY, Kurt R. (1972), The Neogrammarians: A Re-evaluation of their Place in the Development of Linguistic Science. The Hague: Mouton. 
MANLY, John (1912), Note in "Proceedings for 1911." PMLA 27, xix.

MEAD, W.E. (1900), "The Graduate Study of Rhetoric." PMLA 15, Appendix, xix-xxxii.

PAULSEN, Gerard (2013), "The Study of Language and Literature in the Traditional American College (1638-1870)." Celal Bayar University Journal of Social Sciences, 11.2, 28-49.

PEDERSEN, Holger (1962), The Discovery of Language: Linguistic Science in the Nineteenth Century. Trans. John Webster Sparge. 1931; rpt. Bloomington: Indiana UP.

RUDOLPH, Frederick (1977), Curriculum: A History of the American Undergraduate Course Since 1636. San Francisco: Jossey-Bass.

SAMPSON, Geoffrey, (1985). Schools of Linguistics: Competition and Evolution. London: Hutchinson.

SCHLEGEL, Frederich (1849), On the Language and Wisdom of the Indians [Über die Sprache und Weisheit der Indier: Ein Beitrag zur Begründung der Altertumskunde, 1808]. In The Aesthetic and Miscellaneous Works of Frederick von Schlegel. Trans. E.J. Millington. London: Henry G. Bohn.

SHELDON, E.S. (1902), "Practical Philology" MLA Presidential Address, Harvard, December 1901. PMLA 17, 91-104.

SMITH, Alfonso (1899), "The Work of the Modern Language Association of America." PMLA 14, 240-256.

THOMAS, Calvin (1897), "Literature and Personality." MLA Presidential Address, Cleveland, December 1896. PMLA 12, 299-317.

THWING, Charles Franklin (1906), A History of Higher Education in America. NY: D. Appleton.

(1928), The American and the German University: One Hundred Years of History. NY: Macmillan.

VEYSEY, Laurence R. (1965), The Emergence of the American University. Chicago: $\mathrm{U}$ of Chicago P.

WHITE, Andrew D. (1905), Autobiography. Vol. 1. NY: Century. White." The Cornell University Register. 